\title{
HAVAINTOJA JA LASKELMIA LEHMÄVASIKOITTEN SEKÄ HIEHOJEN KASVUSTA VIIKIN KOETILAN KARJASSA
}

\author{
AARNE MÄKELÄ \\ Helsingin yliopiston kotieläintieteen laitos, Viikin koetila
}

Saapunut 5. 9. 1959

Kasvussa on oleellista rakenteellisten kudosten, kuten luitten ja lihasten, lisäys. Sensijaan rasvan kertyminen rasvakudoksiin on vain osaksi kasvulle ominaista. Seuraavassa kiinnitetään huomiota vain ruumiin mittojen ja painon muutoksiin.

Koska on ilmennyt, että elopainon jaluuston kasvu ovat suurelta osalta riippumattomia toisistaan, Eckles ja Anthony (5, s. 269) päättelevät, että painon määrittäminen ei yksinään anna tyydyttävää kuvaa kasvusta. Ruumiin eri osien mitat kuitenkin kasvavat suunnilleen määrätyissä suhteissa, joten yhden mitan, joista säkäkorkeus on helpoimmin mitattavissa, ottaminen riittää. Eläinten kasvu olisi täten mitattava yhdistämällä elopainon ja säkäkorkeuden määrittäminen.

CAmenzindin (2, s. 135) mukaan vasikan syntyessä korkeusmitat (säkäkorkeus, ristiluun korkeus, raajojen pituus) ovat suhteellisesti vahvimmin kehittyneet, leveysja syvyysmitat (rinnan leveys ja syvyys) sensijaan suhteellisesti heikoimmin kehittyneet ja pituusmitat (ruumiin ja rinnan pituus) siltä väliltä. Nuori eläin on tämän mukaan verraten korkea ja kapea täysikasvuiseen verrattuna. Lopullisetkorkeusmitat saavutetaan 3-4 vuoden iässä, lopullinen leveys 5 vuoden iässä, mutta lopullisen painon sonnit saavuttavat 6 ja lehmät vasta 8 vuoden iässä. ENGELERin (ref. 2, s. 134) mukaan ovat lehmän mitat 5 vuoden iässä verrattuna mittoihin 1 kuukauden iässä seuraavat: säkäkorkeus 1.75-, ruumiin pituus 2.3-, rinnan syvyys 2.4-, rinnan leveys 3.0- ja istuinluitten leveys 3.8-kertainen. WaGnerin (ref. 7, s. 486) suorittamien mittausten mukaan lehmän eri mittojen kokonaiskasvusta (syntymästä täysikasvuiseksi) tapahtui ensimmäisenä elinvuotena säkäkorkeudessa $62 \%$, ristiluun korkeudessa $66 \%$, ruumiin pituudessa $56 \%$ ja rinnan leveydessä $59 \%$.

MøllgaArd $(16$, s. 385) ehdottaa kasvun kuvaamiseen suhteellista lisäkasvua, jossa lisäkasvu lausutaan elopainon ja ajan funktiona. Karkea mutta käyttökelpcinen sovellutus tästä on syntymäpainon kaksinkertaistumiseen kuluvan ajan laskeminen. 
DEмвісzAк et al. (4, s. 1133) ovat selvittäneet vasikan kasvun mittaamiseen liittyviä virhemahdollisuuksia. He totesivat, että säkäkorkeus on varmemmin mitattavissa kuin selän pituus.

Nautaeläimen kasvussa on havaittavissa huomattavaa muuntelua, joka johtuu sekä perinnöllisistä että ympäristötekijöistä. Edellisistä rotu on tärkeimpiä. On esimerkiksi tunnettua, että liharotuun kuuluvat yksilöt kasvavat huomattavasti nopeammin kuin tyypilliseen maitorotuun kuuluvat. Perinnöllisistä tekijöistä huomattava on myös sukupuoli. Royn $(20$, s. 16) esittämän useita rotuja käsittävän tilaston mukaan sonnivasikoitten syntymäpaino on $2-4 \mathrm{~kg}$ suurempi kuin lehmävasikoitten. Sonnivasikoitten kasvu parina kolmena ensimmäisenä kuukautena on suunnilleen yhtä suuri kuin lehmävasikoitten. Tämän jälkeen sonnivasikoitten kasvu on nopeampi kuin lehmävasikoitten, ja kuuden kuukauden iässä eroavuutta lisäkasvussa on jo $10-20 \mathrm{~kg}(11, \mathrm{~s} .353 ; 10$, s. 282 ja s. 295). MAC DonALD (12, s. 341) on Uudessa Seelannissa todennut, että Aberdeen Angus- ja Jersey-rotujen risteytyksestä syntyneet sonnit kasvoivat $21 / 2$ vuoden ikään mennessä $60 \mathrm{~kg}$ enemmän kuin hiehot, kun maidon lisäksi laidunruoho oli ainoa rehu $(\mathrm{P}<0.01)$. CAMENzINDin (2, s. 135) Sveitsin ruskeata karjaa koskevan tilaston mukaan lehmän lopullinen paino on n. 15 ja sonnin n. 25 kertaa syntymäpaino.

Perinnöllisyyden ja ruokinnan vaikutusta samaan rotuun kuuluvien lehmävasikoitten kasvuun on BoNNIER (1, s. 221) tutkinut 9 parilla SRB-rotuun kuuluvia identtisiä kaksosia. Jokaisesta parista toinen sai yhden kuukauden iästä 27 kuukauden ikään 3700 ry ja toinen vain 1900 ry. Tällöin edelliset olivat normeihin verrattuna yli- ja jälkimmäiset aliruokinnalla. Kasvua samoinkuin maidontuotantoa seurattiin myös ensimmäisen lypsykauden ajan, ja kaikki eläimet ruokittiin tällöin normien mukaisesti. Runsaasti ruokittujen eläinten elopaino ja säkäkorkeus kehittyivät vasikka- ja hiehokautena nopeammin kuin heikosti ruokittujen, mutta samalla parien välillä ilmeni huomattavasti perinnöllisiä eroavuuksia.

Bonnierin aloittamia kokeita samanmunaisilla kaksosilla jatkaessaan HANsson $(8$, s. 51) on todennut, että vasikka- ja hiehokauden heikko ruokinta tosin hidastaa kasvua, mutta vaikuttaa vain vähän tai ei lainkaan lopulliseen kokoon täysikasvuisella, jollei kasvukauden ruokinta ole ollut aivan puutteellinen. Tämä näyttää osoittavan, että perinnöllisyys johtaa samaan kasvun lopputulokseen riippumatta ruokinnan voimakkuudesta vasikka- ja hiehokautena kohtalaisissa rajoissa. Samaan lopputulokseen pääsi myös PoIJÄRvi (19, s. 567) ryhmäkokeessaan kahdella viiden suomalaisrotuisen lehmävasikan ryhmällä. Lisäksi useat tutkijat $(3$, s. 27 ; 9 , s. 117; 18 , s. 1) ovat todenneet, että niukasti maitoa saaneet tai aikaisin vierotetut vasikat kasvavat ensiksi hitaammin kuin runsaammin ruokitut, mutta jos väkirehua ja vasikoille sopivaa karkearehua on ollut runsaasti saatavissa, painoeroavuudet ovat jo yhden vuoden iässä ainakin suurimmalta osalta hävinneet. Samalla on ilmennyt, että niukka ruokinta vaikuttaa herkemmin painoon kuin säkäkorkeuteen.

FREDERIKSENin (6, s. 1) mukaan lehmävasikoitten syntymäpainon standardipoikkeama on pääasiassa punaisesta tanskalaisesta rodusta kerätyn tilaston mukaan $\pm 4.74 \mathrm{~kg}$ ja muuntelukerroin $12.8 \%$. Ecklesin ja Anthonyn (5, s. 228) mukaan n. $3 / 5$ vasikoista poikkeaa syntymäpainoltaan vähemmän kuin $10 \%$ keskiarvosta kussakin rodussa. Heidän mukaansa rotu on tärkein syntymäpainoa määräävä tekijä 
ja ensimmäinen vasikka on keskimäärin selvästi pienempi kuin myöhemmin syntyneet.

MÄKELÄ ja OitTILA (15, s. 77) saivat Viikin koetilan ayrshirekarjassa tiineysajan pituuden ja vasikan painon välisen vuorosuhteen arvoksi $\mathrm{r}=+0.146 \pm 0.052$ ykkösvasikkatapauksissa, kun vuorosuhde laskettiin koko aineistosta (348 tiineystapausta). Vastaavan lehmien sisäisen vuorosuhteen arvo oli $r=+0.333$ ja regressiokertoimen arvo $\mathrm{b}=+0.395 \mathrm{~kg} / \mathrm{vrk}$. Vasikan painon ja lehmän normaalipainon (paino täysikasvuisena normaalissa lihavuuskunnossa) välinen vuorosuhde oli $\mathrm{r}=+0.113 \pm 0.085$.

\section{Viikin koetilalla suoritettuja ayrshirevasikoitten ja -hiehojen punnituksia ja mittauksia}

Syntymäpaino. Viikin koetilalla on vuodesta 1947 lähtien punnittu vasikat heti syntymän jälkeen. Tähän syntymäpainotilastoon kuuluu 587 elävänä syntynyttä ayrshirerotuista ykkösvasikkaa. Aineistoon kuuluvat sekä lehmä- että sonnivasikat, mutta kuolleena syntyneet ja kaksosvasikat on eliminoitu. Keskimäärin syntymäpaino oli $33.3 \pm 0.20 \mathrm{~kg}$, painon standardipoikkeama $4.9 \pm 0.14 \mathrm{~kg}$ ja muuntelukerroin $14.8 \pm 0.44 \%$. Oheisessa taulukossa esitetään syntymäpainon jakaantuminen.

Vasikoitten syntymäpainon jakaantumistaulu.

The variation of the birth weights of calves of both sexes.

\begin{tabular}{|c|c|c|c|c|c|c|c|c|c|c|c|c|}
\hline $\begin{array}{l}\text { Syntymäpaino } \\
\text { Birth weight } \mathrm{kg}\end{array}$ & $\begin{array}{l}17- \\
19\end{array}$ & $\begin{array}{l}20- \\
22\end{array}$ & $\begin{array}{l}23- \\
25\end{array}$ & $\begin{array}{l}26 \\
28\end{array}$ & $\begin{array}{r}29 \\
31\end{array}$ & $\begin{array}{r}32 \\
34\end{array}$ & $\begin{array}{l}-35- \\
37\end{array}$ & $\begin{array}{l}38 \\
40\end{array}$ & $\begin{array}{l}41- \\
43\end{array}$ & $\begin{array}{l}44- \\
46\end{array}$ & $\begin{array}{l}47- \\
49\end{array}$ & $\begin{array}{c}\text { Yhteensä } \\
\text { Total }\end{array}$ \\
\hline \multicolumn{13}{|l|}{ Tapausten luku } \\
\hline Number of cases & 1 & 7 & 24 & 68 & 119 & 141 & 110 & 71 & 32 & 12 & 2 & 587 \\
\hline
\end{tabular}

Pienin elävänä syntyneen vasikan paino oli $17 \mathrm{~kg}$. Kysymyksessä oli sonnivasikka, jonka emä painoi n. $300 \mathrm{~kg}$. Seuraavaksi keveimpiä oli kaksi 20 kilon vasikkaa. Kaikki kolme olivat ensikkojen vasikoita. Suurin syntymäpaino oli kahdella $47 \mathrm{~kg}$ painavalla vasikalla, joista toinen oli lehmä- ja toinen sonnivasikka. Kummankin emä painoi n. $600 \mathrm{~kg}$.

Aineistossa oli ykkösvasikkoina syntyneinä 288 lehmä- ja 299 sonnivasikkaa. Sekä lehmä- että sonnivasikoista n. 1/4 oli ensikkojen vasikoita. Lehmävasikoitten syntymäpainon keskiarvo oli $32.1 \pm 0.25 \mathrm{~kg}$ ja syntymäpainon standardipoikkeama $4.3 \pm 0.18 \mathrm{~kg}$. Sonnivasikoitten syntymäpainon keskiarvo oli $34.5 \pm 0.30 \mathrm{~kg}$ ja syntymäpainon standardipoikkeama $5.2 \pm 0.21 \mathrm{~kg}$. Sonnivasikoitten paino oli $2.4 \pm 0.39$ kg suurempi kuin lehmävasikoitten $(\mathrm{P}<0.001)$.

Poikimiskerran vaikutusta vasikan syntymäpainoon on tutkittu vertaamalla keskenään ensi- ja toiskantoisten lehmien vasikoitten painoja sekä lisäksi vertaamalla neljänä ensimmäisenä poikimiskertana syntyneitten vasikoitten painoja keskenään. Ensimmäisellä tavalla suoritettavaa vertailua varten aineistossa oli 100 
lehmää, joista tunnettiin sekä ensimmäisen että toisen vasikan paino samalla kun kummassakin vasikkaryhmässä lehmä- ja sonnivasikoitten lukumäärien suhde oli sama, nimittäin 48:52. Ensimmäisenä syntyneitten vasikoitten keskipaino oli $30.9 \pm 0.44 \mathrm{~kg}$ ja toisena syntyneitten $33.3 \pm 0.47 \mathrm{~kg}$. Jälkimmäiset olivat keskimäärin $2.4 \pm 0.65 \mathrm{~kg}$ painavampia kuin edelliset $(\mathrm{P}<0.001)$.

Toisella tavalla suoritettavaa vertailua varten aineistossa oli 41 lehmää, joista tunnettiin vasikan painot neljänä ensimmäisenä poikimiskertana. Vasikoitten jakautuminen sukupuoliin eri poikimiskertoina oli suunnilleen sama. Tilastosta ilmeni, että poikimiskerta vaikutti vasikoitten painoon $(\mathrm{P}<0.01)$. Vasikan keskipaino ensimmäisenä poikimiskertana, $31.2 \mathrm{~kg}$, oli selvästi pienempi kuin kolmena seuraavana poikimiskertana keskimäärin, $33.7 \mathrm{~kg}(\mathrm{P}<0.01)$. Sensijaan vasikoitten painot toisena, kolmantena ja neljäntenä poikimiskertana eivät tilastollisesti merkitsevällä tavalla eronneet toisistaan. Tilastosta ilmeni myös, että lehmien välillä esiintyi vasikoitten painoissa yksilöllisiä eroavuuksia $(\mathrm{P}<0.05)$.

Lehmävasikoitten ja hiehojen painon ja säkäkorkeuden kehityksestä. Viikin koetilalla on vuodesta 1952 lähtien ollut käytännössä lehmävasikoilla standardiruokinta $(14$, s. 276), jossa vasikoille tarjottavat maito- ja väkirehumäärät ovat samat samanikäisillä vasikoilla syntymäpainosta ja emän painosta riippumatta. Heiniä ja vettä vasikat saavat pienestä pitäen vapaasti. Täysimaidon kokonaismäärä on vasikkaa kohti $270 \mathrm{~kg}$, kuoritun maidon $860 \mathrm{~kg}$ ja väkirehun 6 kuukauden ikään asti $68 \mathrm{~kg}$. Hiehojen ruokintaan on sisäruokintakautena sisältynyt 4-6 kg AIV-rehua, heiniä vapaasti sekä $6-12$ kuukauden ikäkautena $1 / 2 \mathrm{~kg}$ väkirehua ja ruokalusikallinen kalanmaksaöljyä päivässä. Hiehojen saama ry- ja srv-määrä täyttää tällöin PALOHEIMOn $(17$, s. 464) esittämät normit. Kesäisin hiehot ovat olleet hyvällä viljelylaitumella.

Kasvua on tarkkailtu suorittamalla määräaikaisia punnituksia ja säkäkorkeuden mittauksia. Punnitukset ja mittaukset on suoritettu syntymästä lukien 2., 5., 9., 13., 17., 21. ja 25. perjantaina sekä lisäksi sinä perjantaina, joka on lähinnä 6 kuukauden ikää. Vastasyntyneet on punnittu, mutta säkäkorkeutta ei ole mitattu, koska vasikoitten hontelo seisontatapa teki tämän vaikeaksi. Lisäksi on hiehot punnittu ja mitattu 1 sekä 1 1/2 vuoden ikäisinä. Punnitukset ja mittaukset ovat tapahtuneet iltaruokinnan päättyessä, nuorempien vasikoitten kohdalla maidon juoton jälkeen.

Tarkasteltuun tilastoon kuuluu n. 90 sellaista lehmävasikkaa, joista on punnitus- ja mittaustuloksia kaikkina edellämainittuina aikoina 6 kuukauden ikään asti. Piirroksessa 1 esitetään näitten vasikoitten keskimääräinen painokäytä ja piirroksessa 2 säkäkorkeuden kehittymistä kuvaava käyrä. Lisäksi kummassakin piirroksessa on piirretty keskiarvokäyrät vasikoille, joiden syntymäpaino on alle $30 \mathrm{~kg}$ ja vasikoille, joiden syntymäpaino on yli $34 \mathrm{~kg}$. Syntymäpainoltaan alle 30 kilon painoisia oli n. $30 \%$ ja yli 34 kilon painoisia n. $25 \%$ koko aineistosta, Edellä mainittuun aineistoon sisältyy 78 sellaista eläintä, jotka punnittiin myös vuoden ja $11 / 2$ vuoden iässä. Näistä on 71 sellaisia, joiden säkäkorkeus mitattiin samoina ajankohtina. Piirroksessa 3 esitetään näitten hiehojen keskimääräinen painokäyrä ja piirroksessa 4 säkäkorkeuden kehittymistä kuvaava käyrä. Elopainon kasvu on keskimäärin ylittänyt FREDERIKSENin kaavan edellyttämät kasvutulokset $(6, \mathrm{~s} .1)$. 


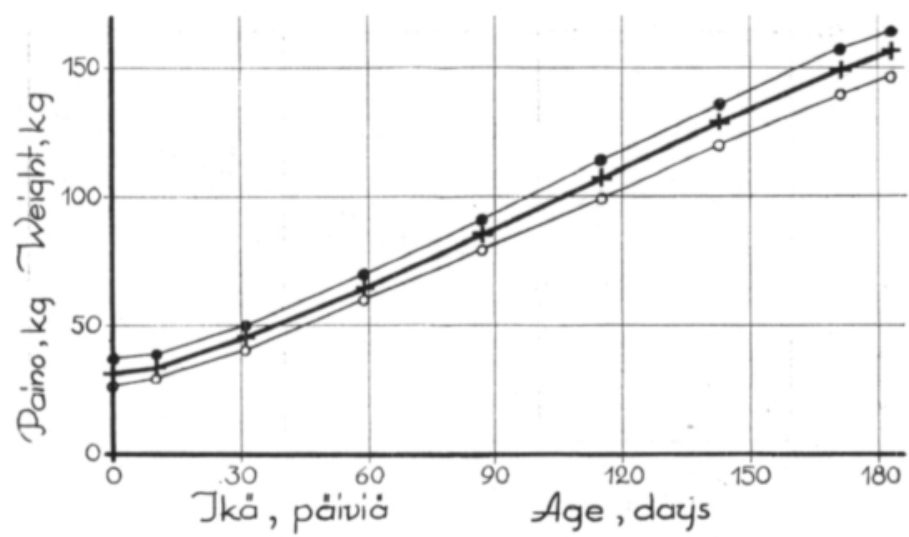

Piirros 1. Lehmävasikoitten painon kehittyminen. Ristit kuvaavat kaikkien vasikoitten keskiarvoja (89 yksilöä), valkoiset ympyrät syntymäpainoltaan alle 30 kilon vasikoita (26 yksilöä) ja mustat ympyrät yli 34 kilon vasikoita (24 yksilöä).

Figure 1. The weight development of heifer calves. The crosses refer to the mean of all the calves (89 individuals), "white circles to calves with a birth weight below $30 \mathrm{~kg}$ ( 26 individuals) and black circles to calves with a birth weight of over $34 \mathrm{~kg}$ (24 individuals).

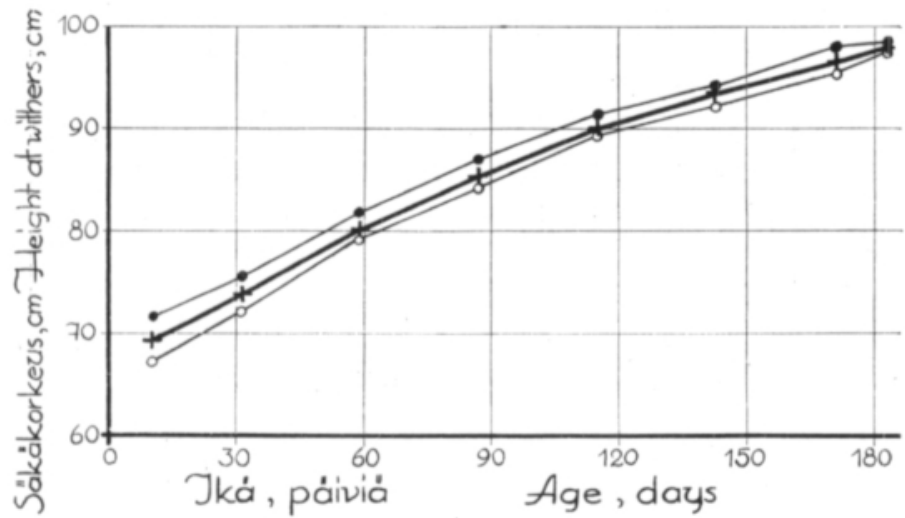

Piirros 2. Lehmävasikoitten säkäkorkeuden kehittyminen. Ristit kuvaavat kaikkien vasikoitten keskiarvoja (88 yksilöä), valkoiset ympyrät syntymäpainoltaan alle 30 kilon vasikoita (28 yksilöä) ja mustat ympyrät syntymäpainoltaan yli 34 kilon vasikoita (21 yksilöä).

Figure 2. The development of height at withers of heifer calves. The crosses refer to the mean of all the calves ( 88 individuals), white circles to calves with a birth weight below $30 \mathrm{~kg}$ (28 individuals) and black circles to calves with a birth weight of over $34 \mathrm{~kg}$ (21 individuals).

Kaavan mukaan vasikan tai hiehon paino $(\mathrm{kg})=\left(\mathrm{M}+2-\frac{(\mathrm{M}+2)^{2}}{100}\right) \cdot 4 \cdot \mathrm{S}$, missä M on eläimen ikä kuukausissa ja S emän paino täysikasvuisena 100 kiloissa. Edelleen elopainon ja säkäkorkeuden kehitys oli yhtä hyvä kuin HeNDERsovin et al. $(10$, s. 282$)$ esittämien taulukoiden mukaan hyvissä ruokintaolosuhteissa kasvatetuilla ayrshire-eläimillä on.

Piirroksesta 1 ilmenee, että jos syntyessä pienikokoisten ja suurikokoisten vasikoitten keskipainot eroavat koko aineiston keskiarvosta n. 5 kilolla ja toisistaan 


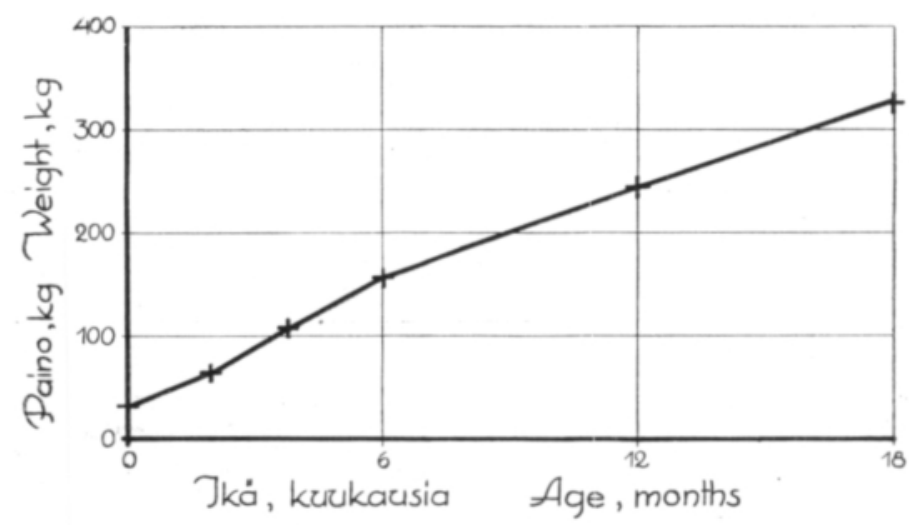

Piirros 3. Hiehojen painon kehittyminen (78 yksilön keskiarvo).

Figure 3. Weight development of heifers (the mean of 78 individuals).

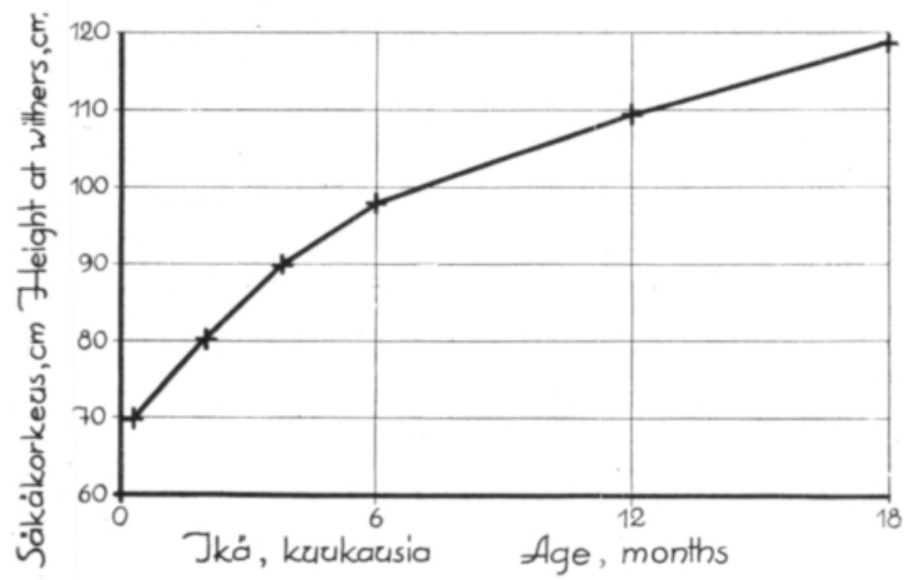

Piirros 4. Hiehojen säkäkorkeuden kehittyminen (71 yksilön keskiarvo).

Figure 4. Development of the height at withers of heifers (the mean of 71 individuals).

n. 10 kilolla, niin tämä eroavuus painoissa säilyy suunnilleen muuttumattomana n. 2 kuukauden ikään asti, ehkä on lähiviikkoina syntymän jälkeen vähän pienempikin. Kaksi kuukautta syntymän jälkeen tämä eroavuus alkaa suureta ja saavuttaa 6 kuukauden iässä jo lähes 20 kilon arvon. Syntymäpainoltaan alle 30 kilon painoiset hiehot olivat yhden vuoden iässä n. $20 \mathrm{~kg}$ ja $1 \frac{1}{2}$ vuoden iässä jo runsaasti $40 \mathrm{~kg}$ kevyempiä kuin yli $34 \mathrm{~kg}$ syntyessä painaneet. Se, että syntyessä suurikokoiset vasikat eivät parina ensimmäisenä kuukautena kasva nopeammin tai kasvavat mahdollisesti hitaamminkin kuin syntyessä pienikokoiset, ilmeisesti suurelta osalta johtuu ruokinnan standardisoimisesta, sillä pienikokoiset vasikat saavat aluksi suhteellisesti runsaamman ruokinnan kuin samanikäiset suurikokoiset, etenkin ensimmäisinä kuukausina, jolloin heinän syönti on vielä vähäistä. Vasikoitten suhteelisen hidas painon lisäys ensimmäisenä elinviikkona johtuu varovaisesta juoton aloittamisesta. 
Tietyssä iässä todetun vasikan tai hiehon painon riippuvaisuus syntymäpainosta voidaan ilmentää myös laskennollisesti. Niinpä 106 lehmävasikkaa käsittävässä aineistossa oli noin 4 kuukauden iässä (17. perjantai) painon ja syntymäpainon välinen vuorosuhde $\mathrm{r}=+0.57$ ja regressiokerroin $\mathrm{b}=+1.24(\mathrm{P}<0.001)$. Kuuden kuukauden painon ja syntymäpainon välinen vuorosuhde oli $\mathrm{r}=+0.55$ ja regressiokerroin $\mathrm{b}=+1.49(\mathrm{P}<0.001)$. Hiehoilla 78 yksilön aineiston mukaan saatiin vastaavasti 1 vuoden iässä $\mathrm{r}=+0.38 \mathrm{ja} \mathrm{b}=+1.70(\mathrm{P}<0.001)$ sekä $11 / 2$ vuoden iässä $\mathrm{r}=+0.57 \mathrm{ja} \mathrm{b}=+3.65(\mathrm{P}<0.001)$. Regressiokerrointen arvojen mukaan yhden kilon enemmyyttä syntymäpainossa vastaa 4 kuukauden iässä keskimäärin $1.24 \mathrm{~kg}: \mathrm{n}$, 6 kuukauden iässä $1.49 \mathrm{~kg}: \mathrm{n}, 1$ vuoden iässä $1.70 \mathrm{~kg}: \mathrm{n}$ ja 1 1/2 vuoden iässä 3.65 kg:n enemmyys. Regressiokerrointen arvot pyrkivät siis kasvamaan iän mukana. Erittäin huomattava on regressiokerrointen eroavuus, $1.95 \mathrm{~kg}(\mathrm{P}<0.02), 1$ ja $11 / 2$ vuoden iässä. Osaltaan tähän on syynä se, että $1 \frac{1}{2}$ vuoden ikäiset hiehot ovat olleet laitumella, missä on mahdollisuus yksilölliseen syöntiin samallakuin rehua on ollut runsaasti, kun sensijaan aikaisemmassa ikävaiheessa ruokinta ollut suuressa määrin standardisoitua. ${ }^{1}$

Piirroksesta 2 nähdään, että säkäkorkeus kasvaa kahtena ensimmäisenä kuukautena n. $1 \frac{1}{2} \mathrm{~cm}, 3-4$ kuukauden iässä $\mathrm{n} .1 \mathrm{~cm}$ ja $5-6$ kuukauden iässä vajaan sentrimetrin viikossa. Syntyessä alle $30 \mathrm{~kg}$ painavien vasikoitten säkäkorkeus oli ensimmäisenä kuukautena keskimäärin n. $4 \mathrm{~cm}$ pienempi kuin syntyessä yli $34 \mathrm{~kg}$ painavien. Ryhmien painoeroavuus syntyessä oli n. $11 \mathrm{~kg}$. Myöhemmin eroavuus säkäkorkeudessa pieneni, ollen $2-3$ kuukauden iässä n. $3 \mathrm{~cm}$ ja $4-6$ kuukauden iässä vain n. $2 \mathrm{~cm}$. Syntyessä alle $30 \mathrm{~kg}$ painavien eläinten säkäkorkeus oli 1 vuoden iässä vain n. $1 \mathrm{~cm}$ ja $1 \frac{1}{2}$ vuoden iässä n. $2 \mathrm{~cm}$ pienempi kuin syntyessä yli $34 \mathrm{~kg}$ painaneitten. Syntyessä suhteellisen kevyitten ja suhteellisen painavien eläinten säkäkorkeuksissa havaittavat eroavuudet näyttävät pienenevän noin yhden vuoden ikään asti, kun sensijaan painoeroavuudet kasvavat. Samoin kuin painoeroavuudet olivat myös säkäkorkeuksien eroavuudet 1 1/2 vuoden iässä suuremmat kuin yhden vuoden iässä. Säkäkorkeuden $1 \frac{1}{2}$ vuoden iässä ja syntymäpainon välinen vuorosuhde oli $\mathrm{r}=+0.35$ ja regressiokerroin $\mathrm{b}=+0.24 \mathrm{~cm} / \mathrm{kg}$.

Syntymästä 2 kuukauden ikään laskettujen painonlisäysten ja syntymäpainon välinen vuorosuhde oli 106 vasikan aineistossa $\mathrm{r}=-0.19$ ja regressiokerroin $\mathrm{b}=-0.22(\mathrm{P}<0.05)$. Syntymästä 4 kuukauden ikään saavutetun painonlisäyksen ja syntymäpainon välinen vuorosuhde oli samassa aineistossa $r=+0.13(0.2>$ $\mathrm{P}>0.05)$. Kuuden kuukauden ikään mennessä vastaava vuorosuhde oli $\mathrm{r}=+0.21$ ja regressiokerroin $\mathrm{b}=+0.46(\mathrm{P}<0.05)$. Päivittäinen lisäkasvu oli syntymästä 6 kuukauden ikään asti aineiston vasikoilla keskimäärin $683 \pm 5.3 \mathrm{~g} / \mathrm{p}$. Kuuden kuukauden iästä yhden vuoden ikään laskettu painonlisäys ei riippunut syntymäpainosta $(\mathrm{r}=+0.07, \mathrm{P}>0.2)$ eikä myöskään 6 kuukauden painosta $(\mathrm{r}=+0.09$, $\mathrm{P}>0.2)$. Tänä aikana saavutettu painonlisäys oli keskimäärin $471 \pm 8.8 \mathrm{~g} / \mathrm{p}$ ja oli

1 Samalla on todettu, että 1 1/2-vuotiaan hiehon ja sen emän normaalipainon välinen vuorosuhde on 74 hiehon aineiston perusteella $\mathrm{r}=+0.19(0.2>\mathrm{P}>0.05)$. Emän normaalipainoksi katsotaan keskinkertaista lihavuuskuntoa vastaavaksi muunnettu paino 3 kk kolmannesta poikimisesta. (Vert. MÄKEц.̈̈ 13, s. 66). 
siis pienempi kuin kasvunopeus ennen 6 kuukauden ikää $(\mathrm{P}<0.001)$. Painonlisäys 1 vuoden iästä $1 \frac{1}{2}$ vuoden ikään oli $451 \pm 15.7 \mathrm{~g} / \mathrm{p}$ eli siis suunnilleen sama kuin kasvunopeus 6 kuukauden iästä yhden vuoden ikään asti.

Elopainon ja säkäkorkeuden kehityksestä on syytä mainita joitakin äärimmäisyystapauksia. Aineistossa oli 5 lehmävasikkaa, joitten syntymäpaino oli vain $21-23 \mathrm{~kg}$. Näistä kolme saavutti 6 kuukauden iässä 140-150 kilon, yhden vuoden iässä $230-250$ kilon ja $1 \frac{1}{2}$ vuoden iässä n. 300 kilon painon, joten niitten painonlisäys oli lähes normaali. Sensijaan kaksi vasikkaa painoi 6 kuukauden iässä vain n. $130 \mathrm{~kg}$, yhden vuoden iässä n. $200 \mathrm{~kg}$ ja $1 \frac{1}{2}$ vuoden iässä n. $250 \mathrm{~kg}$. Säkäkorkeuden kehitys oli lähes normaali paitsi yhdellä vasikalla, jolla säkäkorkeus ja samalla myös paino kehittyivät normaalia tuntuvasti hitaammin. Syntymäpainoltaan yli 40 kilon painoisia lehmävasikoita oli ainoastaan yksi. Sen painon ja säkäkorkeuden kehitys oli normaalia tuntuvasti nopeampi.

Syntymäpainon kaksinkertaisumiseen kuluva aika oli aineiston lehmävasikoilla keskimäärin $57 \mathrm{p}$. Syntyessä alle $30 \mathrm{~kg}$ painavilla vasikoilla (keskipaino 26.3 $\mathrm{kg}$ ) se oli keskimäärin vain $48 \mathrm{p}$, kun sensijaan syntyessä yli $34 \mathrm{~kg}$ painavilla vasikoilla (keskipaino $37.1 \mathrm{~kg}$ ) se oli keskimäärin $65 \mathrm{p}$. Syntyessä kevyet vasikat ovat siis kasvaneet ainakin ensimmäisinä elinviikkoina suhteellisesti huomattavasti nopeammin kuin painavina syntyneet. Tämä pitää paikkansa koko vasikkakautena, sillä 6 kuukauden iässä paino oli koko aineiston vasikoilla 4.9, syntyessä kevyillä vasikoilla 5.6 ja syntyessä painavilla vasikoilla 4.4 kertaa syntymäpaino. Sama ilmenee myös säkäkorkeuden kehityksessä, sillä säkäkorkeus oli 6 kuukauden iässä koko aineistossa keskimäärin 1.41 , syntyessä kevyillä 1.45 ja syntyessä painavilla 1.37 kertaa niin suuri kuin 2. viikkona syntymän jälkeen. Pienenpien vasikoitten suhteellisesti nopeampi kasvu johtunee pääasiallisesti noudatetusta ruokintatavasta, ts. pienempien vasikoitten suhteellisesti runsaammasta ravitsemisesta.

Samasta aineistosta kuin painonlisäys on laskettu myös painonlisäysten hajonta eri ikäkausina. Painonlisäysten standardipoikkeama syntymästä kuuden kuukauden ikään oli $9.5 \pm 0.68 \mathrm{~kg}$ ja muuntelukerroin $7.6 \pm 0.55 \%, 6$ kuukauden iästä yhden vuoden ikään oli standardipoikkeama $15.9 \pm 1.14 \mathrm{~kg}$ ja muuntelukerroin $18.5 \pm$ $1.37 \%$, yhden vuoden iästä $1 \frac{1}{2}$ vuoden ikään oli standardipoikkeama $26.2 \pm 2.03$ $\mathrm{kg}$ ja muuntelukerroin $31.8 \pm 2.71 \%$. Painonlisäysten standardipoikkeama ja vielä huomattavammin muuntelukerroin kasvavat siis eläinten vanhetessa. Painonlisäykseen yhden vuoden iästä $1 \frac{1}{2}$ vuoden ikään vaikuttaa oleellisesti se seikka, kuuluuko laidunkausi tähän aikaan vai ei. Asian tarkistamiseksi on vertailtu hiehoja, jotka syys-marraskuun aikana ovat täyttäneet $1 \frac{1}{2}$ vuotta ( 29 yksilöä), hiehoihin, jotka maalis - toukokuussa ovat täyttäneet $1 \frac{1}{2}$ vuotta (14 yksilöä). Edellisen ryhmän hiehoilla viimeiseen puolivuotisjaksoon kuuluu laidunkausi joko kokonaan tai miltei kokonaan, kun sensijaan jälkimmäisen ryhmän hiehoilla tämä aika on joko kokonaan tai miltei kokonaan sisäruokintakautta. Edellisen ryhmän hiehojen painonlisäyksen keskiarvo yhden vuoden iästä $1 \frac{1}{2}$ vuoden ikään oli $535 \pm 27.6 \mathrm{~g} / \mathrm{p}$ ja jälkimmäisen ryhmän hiehojen $378 \pm 23.9 \mathrm{~g} / \mathrm{p}$. Tässä ikävaiheessa laitumella olleet hiehot kasvoivat siis $157 \pm 36.5 \mathrm{~g} / \mathrm{p}(\mathrm{P}<0.001)$ enemmän kuin sisällä olleet.

Punnituksia ja säkäkorkeuden mittauksia suoritettiin myös 15 sonnivasikalla, jotka olivat samalla standardiruokinnalla kuin lehmävasikat. Näitten sonnivasi- 
koitten keskimääräinen paino oli syntyessä $3.6 \mathrm{~kg}(\mathrm{P}<0.01)$ suurempi kuin lehmäyasikoitten. Noin 2 kuukauden iässä oli sonnivasikoitten paino $3.3 \mathrm{~kg}(\mathrm{P}<0.02), 4$ kuukauden iässä $9.6 \mathrm{~kg}(\mathrm{P}<0.001)$ ja 6 kuukauden iässä $20.3 \mathrm{~kg}(\mathrm{P}<0.001)$ suurempi kuin lehmävasikoitten. Kahtena ensimmäisen elinkuukautena sonni- ja lehmävasikoitten painonlisäys oli suunnilleen yhtä nopea, mutta senjälkeen sonnivasikoitten oli nopeampi. Säkäkorkeuksissa ei ollut mainittavaa eroavuutta sonni- ja lehmävasikoitten välillä syntymästä 6 kuukauden ikään asti.

Painon ja säkäkorkeuden vertailua. Vasikoitten painoja ja säkäkorkeuksia käsittävän tilaston perusteella voidaan arvioida punnitusten ja säkäkorkeuksien mittausten keskinäinen arvo vasikan kasvun seuraamisessa. Painon kehitys on suhteellisesti nopeampi kuin säkäkorkeuden kehitys. Esimerkiksi 6 kuukauden iässä vasikoitten keskipaino oli 4.9 kertaa ja 1 1/2 vuoden iässä 10.3 kertaa syntymäpaino. Säkäkorkeus oli keskimäärin 6 kuukauden iässä sensijaan vain 1.41 ja 1 1/2 vuoden iässä 1.70 kertaa säkäkorkeus 2. viikkona. Edelleen painojen suhteellinen hajonta määrätyssä iässä on suurempi kuin säkäkorkeuksien hajonta. Niinpä painojen muuntelukerroin (standardipoikkeama prosenteissa keskiarvosta) oli syntymäaikana n. $14 \%$ ja 2 kuukauden iästä $1 \frac{1}{2}$ vuoden ikään $8-9 \%$. Standardipoikkeaman arvo oli esim. 6 kuukauden iässä $11.9 \pm 0.82 \mathrm{~kg}$ ja $1 \frac{1}{2}$ vuoden iässä $29.5 \pm 2.36 \mathrm{~kg}$. Säkäkorkeuksien muuntelukerroin oli vasikkakautena n. $3 \%$ ja hiehokautena n. $2 \frac{1}{2} \%$. Standardipoikkeama määrätyssä iässä sekä vasikka- että hiehokautena oli vain n. $3 \mathrm{~cm}$. Painojen standardipoikkeama on eläinvaa'an punnitustarkkuuteen verrattuna varsin suuri, kun sensijaan säkäkorkeuksien hajonta on vain vähän suurempi kuin mahdollinen mittausvirhe. Punnitustuloksissa aiheuttaa virheellisyyttä vaihteleva ruoansulatuskanavan sisällön määrä. Täten aiheutuva virhe lienee vasikoilla kuitenkin suhteellisen vähäinen (4, s. 1133). Painojen suhteellisesti nopeammasta kehityksestä ja suhteellisesti suuremmasta hajonnasta sekä tarkemmasta määrittämisestä säkäkorkeuksien vastaaviin ominaisuuksiin verrattuna johtuu, että vasikoitten kasvun yksilöllisyys ilmenee selvemmin punnitustuloksista kuin säkäkorkeuden mittaustuloksista.

Koska vasikoilla voi elopainon lisäystä tapahtua myös luuston kasvusta riippumatta, lihoamisen muodossa, olisi kasvun seuraamisessa punnitusten lisäksi otettava jokin luuston kokoa kuvaava mitta, joista säkäkorkeus ehkä on helpoin suorittaa. Painon ja säkäkorkeuden välisen riippuvaisuussuhteen selvittämiseksi on laskettu niitten välinen vuorosuhde. Vuorosuhteen arvo oli 9 . viikkona $\mathrm{r}=+0.57$ $(\mathrm{P}<0.001)$, 17. viikkona $\mathrm{r}=+0.58(\mathrm{P}<0.001)$ ja 6 kuukauden iässä $\mathrm{r}=+0.50$ $(\mathrm{P}<0.001)$. Koko lehmävasikka-aineistossa iän vaikutus eliminoituna vuorosuhteen arvo oli $\mathrm{r}=+0.53(\mathrm{P}<0.001)$. Vuorosuhteen arvoista voidaan päätellä, että samanikäisillä vasikoilla elopainon ja säkäkorkeuden välillä vallitsee selvä riippuvaisuussuhde, mutta että samalla nämä molemmat kasvun karakteristikat muuntelevat huomattavasti toisistaan riippumatta. Tämän vuoksi ei punnitusten perusteella ole mahdollista arvioida säkäkorkeuden kehitystä eikä myöskään päinvastoin, vaan kasvun tarkkailemiseksi on parasta turvautua sekä punnitsemiseen että säkäkorkeuden mittaamiseen. 
Viikin koetilan ayrshirekarjassa on vuodesta 1947 lähtien määritetty vasikoitten syntymäpaino ja vuodesta 1952 lähtien elopaino ja säkäkorkeus määräajoin. Samoin hiehot on punnittu ja mitattu 1 ja 1 1/2 vuoden ikäisinä. Lehmävasikoitten ruokinnassa on ollut käytännössä ns. standardiruokintajärjestelmä, missä maito- ja väkirehumäärät ovat samat samanikäisillä vasikoilla syntymäpainosta ja emän painosta riippumatta, mutta heinien ja veden saanti on ollut vapaa. Vasikoitten painoista ja säkäkorkeuksista todettiin mm. seuraavaa.

Lehmävasikoitten syntymäpainon keskiarvo oli $32.1 \pm 0.25 \mathrm{~kg}$, standardipoikkeama $4.3 \pm 0.18 \mathrm{~kg}$ ja muuntelukerroin $13.4 \pm 0.57 \%$, kun aineiston muodostivat ykkösvasikkoina ja elävänä syntyneet. Sonnivasikoitten paino oli keskimäärin $2.4 \mathrm{~kg}(\mathrm{P}<0.001)$ suurempi kuin lehmävasikoitten. Ensikantoisten lehmien vasikat olivat keskimäärin $2.5 \mathrm{~kg}(\mathrm{P}<0.01)$ kevyempiä kuin 2., 3. ja 4. poikimiskertana keskimäärin.

Lehmävasikoilla niin painon kuin säkäkorkeuden lisäys on kahtena ensimmäisenä elinkuukautena melko lailla riippumaton syntymäpainosta. Vasta myöhemmin syntymäpainoltaan suurilla vasikoilla lisääntyy paino nopeammin kuin pienillä (piirrokset 1 ja 3). Suhteellinen kasvunopeus, niin painon kuin säkäkorkeuden perusteella arvosteltuna, on jälkimmäisellä suurempi kuin edellisillä. Säkäkorkeuden absoluuttinen lisäys näyttää ainakin $1 \frac{1}{2}$ vuoden ikään asti olevan melko lailla riippumaton syntymäpainosta (piirrokset 2 ja 4). Säkäkorkeudenkin suhteellinen kehitys on syntymäpainoltaan pienillä vasikoilla nopeampi kuin syntymäpainoltaan suurilla vasikoilla. Pienempien vasikoitten suhteellisesti nopeampi painon lisääntyminen johtunee ensimmäisinä elinkuukausina pääasiallisesti noudatetusta standardiruokintajärjestelmästä.

Sonnivasikoitten painon kehitys oli kahtena ensimmäisenä elinkuukautena suunnilleen samansuuruinen kuin lehmävasikoitten, myöhemmin nopeampi.

Painojen suhteellisesti suuremmasta hajonnasta ja tarkemmasta määrittämisestä sekä suhteellisesti nopeammasta kehityksestä säkäkorkeuden vastaaviin seikkoihin verrattuna johtuu, että vasikoitten kasvun yksilöllisyys ilmenee selvemmin punnitustuloksista kuin säkäkorkeuden mittaustuloksista.

Painon ja säkäkorkeuden välinen vuorosuhde oli lehmävasikoilla iän vaikutus eliminoituna $\mathrm{r}=+0.53(\mathrm{P}<0.001)$. Paino ja säkäkorkeus muuntelivat siis huomattavasti riippumatta toisistaan. Senvuoksi on syytä seurata vasikoitten kasvua määrittämällä määräajoin sekä elopaino että säkäkorkeus. 


\section{KIRJALLISUUTTA}

(1) Bonnier, G. 1946. Samspelet mellan arv och miljö i nötkreatursproduktionen, belyst genom tvillingstudier. Särtryck ur Kungl. Lantbruksakademiens Tidskrift 85: 221-240.

(2) Camenzind, T. 1944. Handbuch der Rindviehzucht und -Pflege. 583 s. Bern.

(3) Converse, H. T. 1949. Experiments in rearing calves without whole milk and with limited amounts of skim milk. United States Dep. Agric., Circular No. 822. 31 s.

(4) Dembiczak, C. M., Eaton, H. D. \& Beall, G. 1957. Design and conduct of calf nutrition studies. 1. One- vs. two- and three-day growth measurements. J. Dairy Sci. 40: 1133-1151.

(5) Eckles, C. H. \& Antony, E. L. 1956. Dairy cattle and milk production. 587 s. New York.

(6) Frederiksen, L. 1929. Oplysningen om nogle danske Opdraetningsforsøg med Kvaeg. Beretning fra N. J. F:s Kongres i Helsingfors, Juli 1929, s. 1-14. Fortryk.

(7) Hansen, J. 1922. Lehrbuch der Rinderzucht. 647 s. Berlin.

(8) Hansson, A. 1956. Influence of rearing intensity on body development and milk production. Proc. Brit. Soc. Anim. Prod., s. 51-66.

(9) Hedler, L. 1952. Untersuchungen über den Einfluss einer milcharmen Jugendernährung auf die Körperentwicklung und die Verdauungsvorgänge bei Kälbern. Z. Tierzüchtung und Züchtungsbiologie 60: 117-172.

(10) Henderson, H. O., Larson, C. W. \& Putney, F. S. 1938. Dairy cattle feeding and management. 557 s. New York.

(11) Krüger, L. \& Schulze, G. 1956. Ein Beitrag zur Nährstoffversorgung von Kälbern. Arch. für Tierern. 6: $353-374$.

(12) Mac Donald, M. A. 1958. Seasonal growth relationships in Aberdeen Angus $\times$ Jersey crossbred cattle. Repr, from The New Zealand J. Agric. Res. 1: 341-348.

(13) MÄкеLÄ, A. 1956. Studies on the question of bulk in the nutrition of farm animals with special reference to cattle. Acta Agr. Fennica 85: 1-130.

(14) —- 1958. Viikin opetus- ja koetilalla noudatettu lehmävasikoitten ruokintajärjestelmä. Maatal.tiet. aikak. 30: $276-292$.

(15) —- \& Ortrila, R. 1955. Tiineysajan pituus Viikin opetus- ja koetilan ayrshirekarjassa. Ibid. 27: $77-84$.

(16) Møllgand, H. 1941. Laerebog i grundtraekkene af husdyrenes ernaeringsfysiologi. 505 s. Kjøbenhavn.

(17) Palohermo, L. 1956. Kotieläinhoidon perusteita. 619 s. Jyväskylä.

(18) Percival, J. C. 1951. Early weaning of calves. Repr. from The Proc. of the Ruakura Farmers' Conference Week, $7 \mathrm{~s}$.

(19) PoIJÄRvI, I. 1953. Kasvuiän ruokinnan vaikutuksesta lypsylehmien tuotantoon ja kestävyyteen. Karjatalous 29: 567-572.

(20) Roy, J. H. B. 1955. The calf. Its management, feeding and health. 79 s. London.

S U M M A R Y :

OBSERVATIONS AND CALCULATIONS CONCERNING THE GROWTH OF HEIFER CALVES AND HEIFERS ON THE VIIK UNIVERSITY FARM

\section{AARNe MÄKEL Ä}

Department of Animal Husbandry, University of Helsinki

In the Ayrshire herd of the University Farm Viik the calves have been weighed at birth since 1947, and the weight and the height at withers measured at stated intervals since 1952. Similarly heifers have been weighed and measured at the ages of 1 and $1 \frac{1}{2}$ years. In the feeding of heifer calves a standard feeding system has been used in which the allowance of milk and of concentrates has been the same at the 
same age irrespective of the birth weight and of the weight of the mother. Hay and water, however, have been given ad libitum since birth. The total allowance of whole milk per calf has been about $270 \mathrm{~kg}$, of skimmilk about $860 \mathrm{~kg}$, and of concentrates until six months of age about $68 \mathrm{~kg}$. The main results as to the weights and the heights at withers were as follows.

The mean of the birth weight of 288 heifer calves was $32.1 \pm 0.25 \mathrm{~kg}$, the standard deviation being $4.3 \pm 0.18 \mathrm{~kg}$, and the coefficient of variation $13.4 \pm 0.57 \%$ when the subject matter included only the single birth cases. The variation of birth weight can be seen from table page 305 . The birth weight of the bull calves was on an average $2.4 \mathrm{~kg}(\mathrm{P}<0.001)$ more than that of the heifer calves. The calves of the first calving were on an average $2.5 \mathrm{~kg}(\mathrm{P}<0.01)$ lighter than those of the second, third, and fourth calving.

The gain in weight of heifer calves is in the two first months from birth relatively independent of the birth weight. Thereafter the calves with a great birth weight grow faster than the calves with a small birth weight. Figures 1 and 3 show the weight developments of heifer calves and of heifers. The increase in height at withers seems to be relatively independent of the birth weight (Figures 2 and 4 ). The relative rate of growth measured as a gain in weight and increase in height at withers is greater in calves with small birth weight. The relatively faster gains in weight of calves with small birth weight during the first months of life may principally be due to the standard feeding system.

In the two first months the increase in weight of the bull calves is about the same as that of the heifer calves. Later the bull calves grow faster.

As to the live weight the standard deviation is relatively greater, the measuring more accurate, and the gain relatively faster than in the case of the height at withers, the individuality of the growth of calves manifests itself more clearly in weights than in the heights at withers.

The correlation coefficient between the weight and the height at withers was for the heifer calves $\mathbf{r}=+0.53(\mathrm{P}<0.001)$ the influence of age being eliminated. The weight and the height at withers thus vary considerably independently of each other. Therefore it is advisable in observing the growth development of calves not only to weigh the animals but also to measure their height at withers. 